\title{
МІЖНАРОДНЕ СПІВРОБІТНИЦТВО
}

УДК [902:001.83](477+560)

С. О. Біляєва, Л. В. Кулаковська, О. С. Фіалко

\section{УКРАЇНА — ТУРЕЧЧИНА: ГРАНІ СПІВРОБІТНИЦТВА}

Співробітниитво Украӥни $i$ Туреччини наприкіниі XX-на початку XXI cm. в галузі археології османських пал'яток розвивалося в різних напрямах: розкопки, польові та наукові розвідки, видання наукових праць, виставки, створення Історико-культурної асочіацї "Україна - Туреччина", Міжнародні наукові конфберениії.

Ключові слова: Україна, Туреччина, археологічні дослідження, співробітниитво.

\section{ВСТУП}

Наукове співробітництво України і Туреччини в галузі археології уможливила руйнація політичної та ідеологічної системи Радянського союзу і набуття Україною незалежності. Саме тоді розпочалося налагодження зв'язків 3 науковцями країн, що були небажаними за часів комуністичного режиму, і настав час вивчення заборонених тем, залучення нових підходів до історії цивілізаційного розвитку України у контактному середовищі тюркських народів. Iз 1989 р. експедиція Інституту археології НАН України розпочала археологічні дослідження історичного центру Очакова, відтак, поступово накопичувалася фрактично нова для археології України колекція матеріальної культури Північного Причорномор'я часів Золотої Орди, Кримського ханату й Османської держави. У загальноісторичному та методологічному сенсі формування цілеспрямованого вивчення османської археології в Україні співпадає в часі з становленням ціеї галузі як окремого напряму досліджень у світовій археологічній науці та появою перших теоретичних і практичних розробок (Baram, Carrol 2000). Коротко схарактеризуємо історію налагодження контак-

( С. О. БІЛЯЄВА, Л. В. КУЛАКОВСЬКА, О. Є. ФІАЛКО, 2019 тів і сорери українсько-турецького співробітництва.

\section{ПОЛЬОВІ ДОСЛІДЖЕННЯ ТА ПУБЛІКАЦІЯ ЇХ РЕЗУЛЬТАТІВ}

У ході розкопок османських пам'яток на теренах нинішньої України Південна середньовічна археологічна експедиція Інституту археології НАНУ накопичила чисельну колекцію артефрактів, які дещо відрізняються від типових для цього регіону знахідок. Відтак постала необхідність консультації 3 фрахівцями 3 Туреччини. 1996 р. за сприяння співробітника Інституту сходознавства НАН України канд. істор. наук В. Остапчука українські археологи звернулися до посла Республіки Туреччини в Україні, пана Аджара Гермена. Пан посол, своєю чергою, звернувся до тодішнього голови Турецької історичної асоціації профр. Юсуфра Халач Оглу з проханням допомогти консультаціями українським археологам. Початок контактів українських і турецьких вчених заклав приїзд до України професора університету Анкари Боскурта Ерсоя, який взяв участь у обстеженні історичного центру Очакова і ознайомився не лише із знахідками експедиції, а й з експозицією та фрондовими колекціями Військово-історичного музею ім. О. В. Суворова у м. Очаків. Зустріч була досить плідною і довела доцільність організаціі спільних наукових проектів. У $1997-1998$ рр. було реалізовано перший спільний проект Турецької історичної асоціації та Інституту археології НАНУ з дослідження османських пам'яток в Очакові, насамперед, залишків фортеці Озі та міста навколо неї. Так розпочалася спільна робота українсько-турецької експедиції під керівництвом канд. іст. наук 


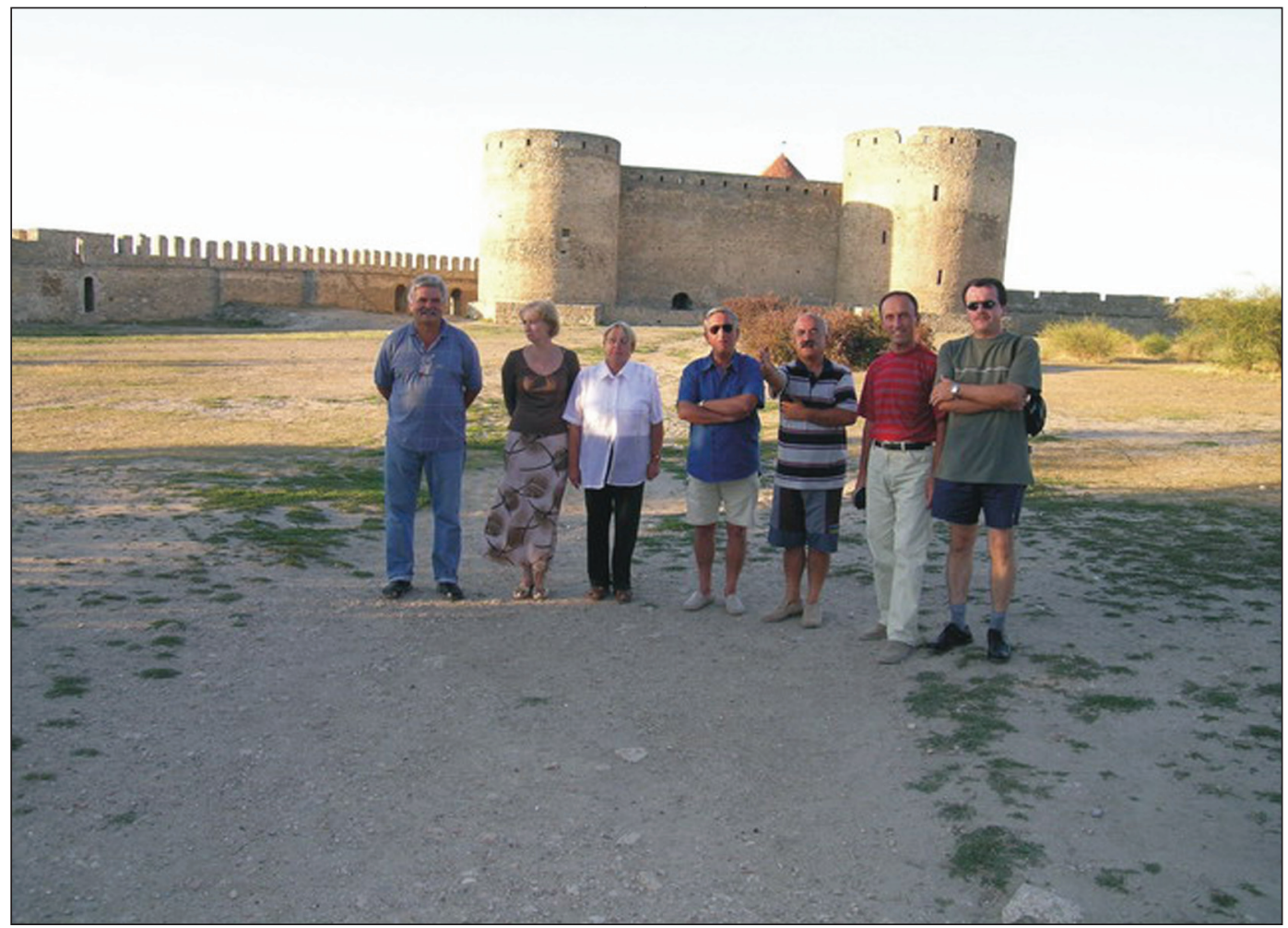

Білгород-Дністровський, 2005 р. Представники Міжнародної українсько-турецької експедиції IA НАН України, які брали участь у розкопках Аккерманської фортеці. Зліва направо: заступник начальника експедиції Ю. В. Болтрик, О. Є. Фіалко, начальник експедиції С. О. Біляєва, керівник експедиції з турецького боку Б. Ерсой, співробітники експедиції С. Байракал, С. Тунчоку, Х. Урер

Світлани Біляевої з боку України та профр. Бозкурта Ерсоя з боку Туреччини. Від Інституту археології НАН України в експедиції у різні роки брали участь: док. істор. наук О. В. Сухобоков, кандидати істор. наук Ю. В. Болтрик, О. Є. Фіалко, Л. І. Виногродська, а також Г. О. Станіцина, I. В. Карашевич та ін. Турецьку сторону представляли профр. док. І. КуюлуЕрсой, доц. док. Р. Бозер, док. С. Тунчоку, док. Х. Урер, док. Н. Чамаш, С. Байракал, Х. Учар. Розкопки дали важливі відкриття, що стосуються історії міста, зокрема, виявлено фррагмент будівельної забудови і з'ясовано конструктивні особливості фрортеці. Зовнішня їі стіна була зведена $з$ сирцевої цегли, внутрішня - 3 оброблених плит вапняку і ракушняка. Простір між ними був заповнений дрібним камінням і землею. Саме таку конструкцію описано в одному 3 меморандумів очаківських правителів Хасан Паші та Ісмаїла Паші 1710 р. (Finkel, Ostapchuk 2005, p. 176, 179). За планом початку XVIII ст., стіна була складовою північної ділянки фортифікації. У фррагменті виявленої стіни, у кладщі, було вмуроване кам'яне ядро, що становить конструктивну особливість захисних мурів багатьох європейських фортець, зокрема i деяких Північного Причорномор'я, як Білгород-Дністровська фортеця. За межами фортеці на території міста була досліджена ділянка забудови XVII-XVIII ст. (ур. Левада) 3 залишками будівель і водостоком.
Колекція артедрактів репрезентуе широкий спектр турецької культури: знаряддя, зброя, побутові речі, деталі одягу, прикраси, вироби 3 глини (посуд і люльки для куріння), монети. Також виявлено типовий керамічний посуд i вироби з гутного скла, характерні для української культури. Важливою знахідкою були фррагменти кераміки сграфріто, знайдені in situ. Подібні артефакти є прикметними для передосманського періоду Очакова XIV-XV ст., власне до зведення містечка кримським ханом Менглі Гіреєм у 1492 р. Ці дані уможливлюють уточнити час існування міста і по-новому інтерпретувати історію його заснування. Результати досліджень відображено у спільних доповідях на Міжнародному конгресі з турецької культури в Анкарі 1997 р., на конфреренції «Часи козацькі» та у публікаціях в Україні й Туреччині (Біляєва, Ерсой 1998; 1999; 2000; Біляева та ін. 1998; Biliaieva 1999; Biliaieva, Ersoy 1999).

У 1999 -2002 рр. за спільними проектами Інституту археології НАН України і Турецького У правління співробітництва та розвитку (ТІКА) візуально обстежено османські пам'ятки, зроблено обміри, фото і графрічну фріксацію фортець, окремих пам'яток монументальної архітектури (мечеті, медресе, караван-сараї) на території міст, а також поховальних пам'яток (надгробні стели, мавзолеї) на території Одеської, Хмельницької, Чернівецької областей і Автономної Республіки Крим. 


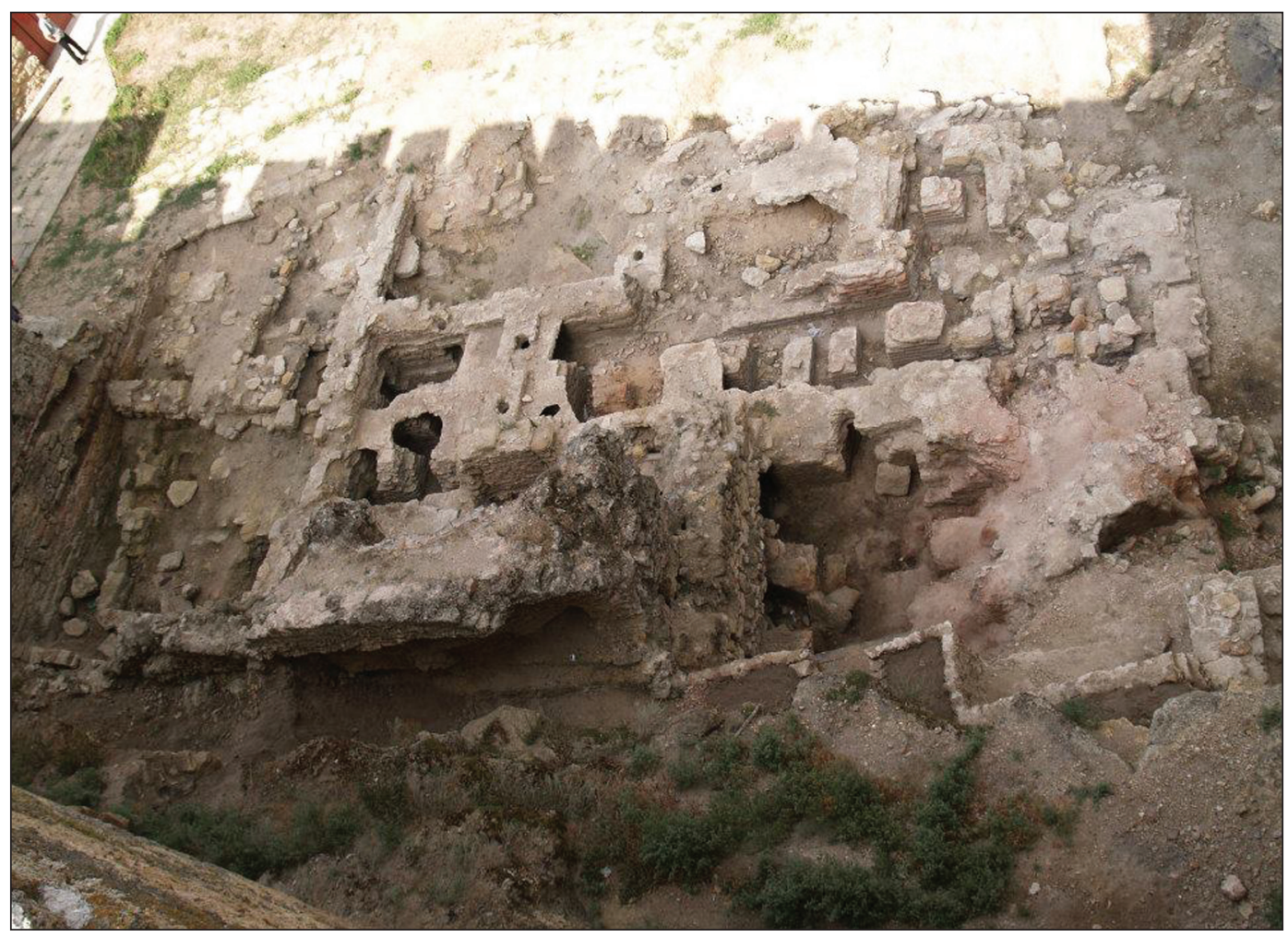

Білгород-Дністровський. Аккерманська фрортеця. Турецька лазня, досліджена вченими України та Туреччини

З 1999 р. розпочалося дослідження Аккерманської фортеці у м. Білгород-Дністровський Одеської обл. У 2004-2006 рр. роботи виконувалися за підтримки Турецького управління співробітництва і розвитку (ТІКА) при Раді міністрів Республіки Туреччина. Основні роботи експедиції провадилися у Четвертому нижньому дворі фортеці. Головним об'єктом робіт 1999-2002 рр. була турецька лазня, у 20042006 pp. - фортифікація нижньої лінії укріплень, головне місце у якій посідав барбакан.

Дослідження турецької лазні виявило особливості ї̈ планування та архітектури, встанов-

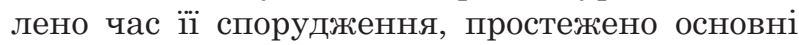
етапи фрункціонування та перебудови лазні на майстерню з виробництва і зберігання свинцевих виробів (кулі, шрапнель, важки тощо). У подальшому вдалося розробити методику реконструкщії даху приміщень лазні і споруди загалом (Біляева, Карашевич, Фіалко 2006). Зіставлення писемних і археологічних джерел допомогло уточнити час побудови лазні, ïi значення в інфраструктурі фортеці, зокрема у виконанні обов'язкового омовіння перед намазом. Ідеться власне про організацію єдиного сакрального комплексу: лазні у Нижньому дворі та Великої мечеті у громадському дворі у 1484-1512 pр. (Шлапак 2001, с. 47), що було надзвичайно важливим елементом забезпечення щоденної життедіяльності турецького гарнізону за ісламськими звичаями.

Наступним важливим об'єктом досліджень був барбакан як конструктивна та оборонна частина Нижньої захисної лінії. Вивчення цього об'єкта через фрінансові та інші обставини не було завершено. Проте результати цих робіт уможливили реконструювати розвиток барбакану (Біляєва, Мартинюк-Медвецька, Присяжний 2008) і встановити, що він був частиною Нижньої фортифіккаційної лінії. В Османський період барбакан зазнав істотної перебудови, пов'язаної зі спорудженням бастіонів і проведенням інших заходів, націлених на посилення обороноздатності. Ці історичні моменти мають підтвердження у документах з Архіву прем'єрміністра у Стамбулі (Finkel et al. 2006, p. 12; 2007, p. 11-14).

Дуже репрезентативною є колекція артефактів з розкопок барбакану (Біляева та ін. 2007), що за складом і асортиментом знахідок відрізняеться від комплексу з лазні. Завважимо, що серед матеріалів барбакану мало віконного скла на відміну від лазні, де воно було важливим конструктивним елементом освітлення приміщень. $\mathcal{E}$ певна специфіка й щодо складу озброєння, зокрема, у наявності уламків скляних гранат, що долітали до барбакану з лиману під час військових дій тощо (Біляева, Фіалко 2018). У результаті розкопок на території Аккерманської фортеці суттево змінилися і збагатилися наші уявлення про історію та культуру Північного Причорномор'я за доби середньовіччя та раннього модерну.

Наступним кроком співробітництва, зокрема, в польових дослідженнях, була участь С. О. Біляевої як експерта з кераміки у роботі 


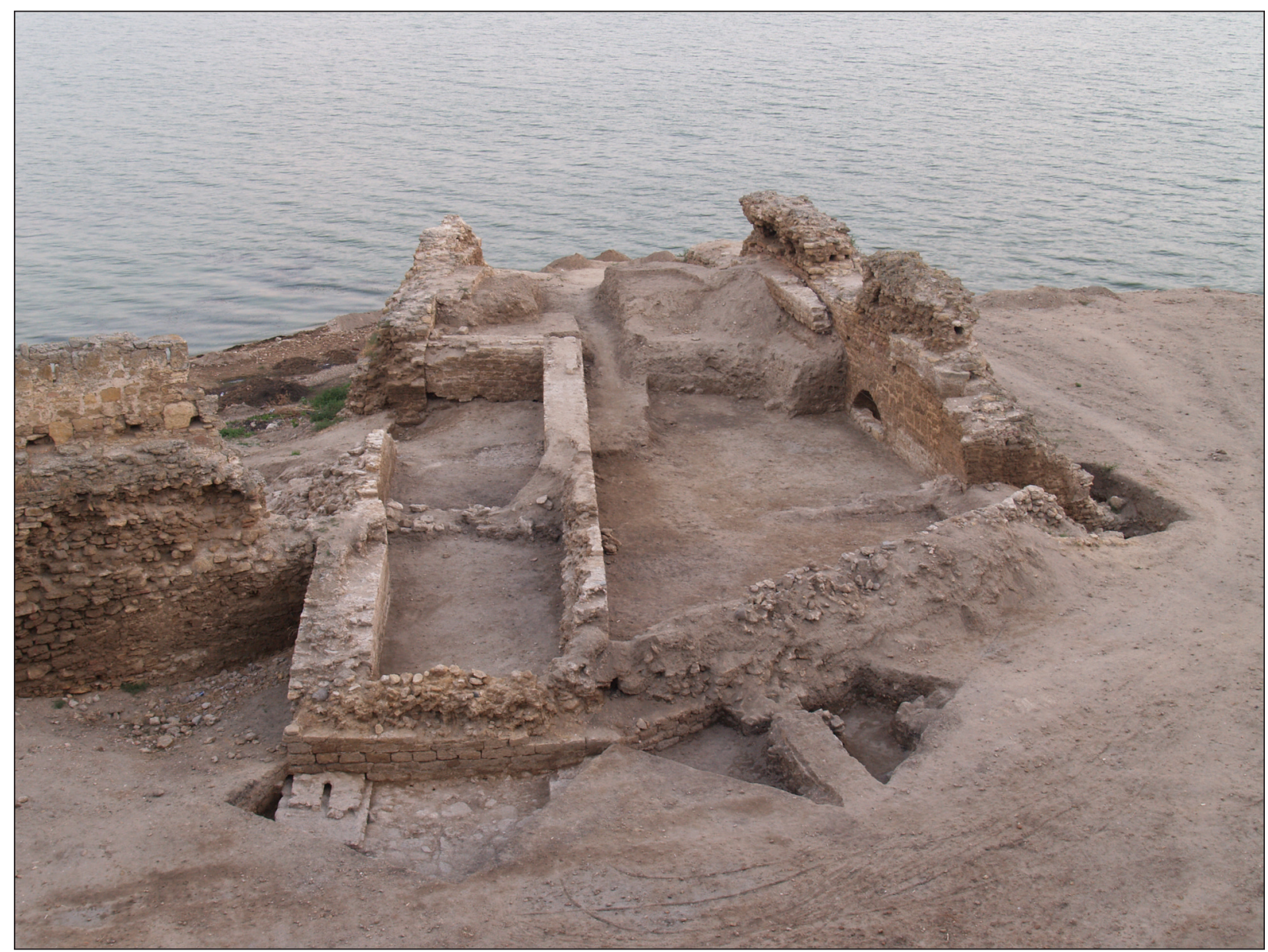

Білгород-Дністровський. Аккерманська фортеця. Барбакан

Під час роботи експедиції у м. Кале, Туреччина

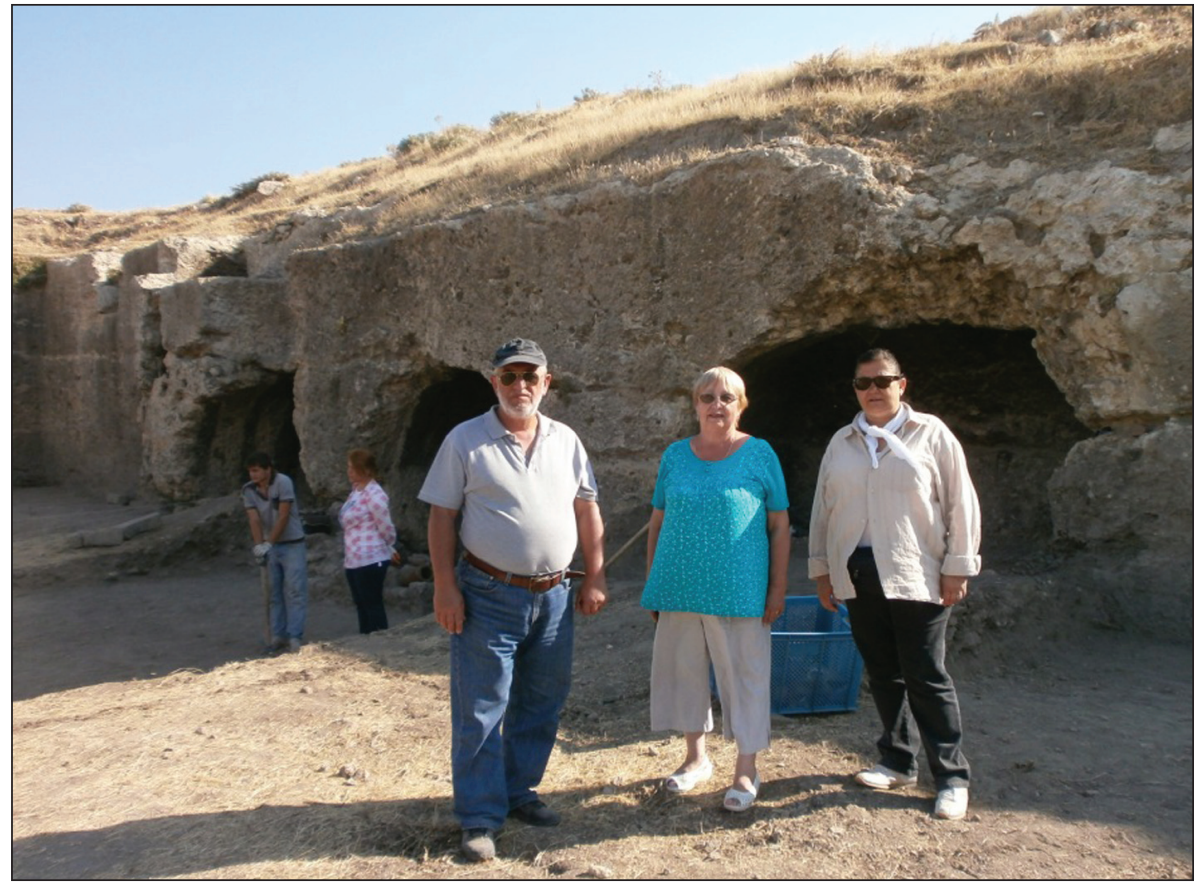

археологічної експедиції Егейського університету (м. Ізмір) у 2013 р., яка провадила дослідження поблизу різночасового комплексу (від римського часу до модерну) м. Кале. Важливим об'єктом для порівняльного вивчення особливостей конструкції та планувальної структури османської лазні у Білгороді-Дністровській (Аккерманській) фрортеці стала відкрита і досліджена у Кале лазня сельджуцького часу. 


\section{ВВЕДЕННЯ ДО НАУКОВОГО ОБІГУ НАБУТКІВ УКРАЇНСЬКО- ТУРЕЦЬКИХ ПРОЕКТІВ}

Результати спільних археологічних досліджень представлялися у формі доповідей і презентацій учасників експедиції з українського i турецького боків на різних наукових форумах в Україні та за кордоном: у Киеві на щорічних конференціях «Часи козацькі», на яких з 2006 р. діяла спеціальна тематична секція з тюркології, на читаннях в Інституті сходознавства НАН України, регіональних тематичних конференціях у Миколаєві та Очакові. Перші результати робіт демонструвалися на Конгресі з історії турецької культури у 1997 р. У подальшому нові матеріали та певні розробки звучали на Міжнародних форумах в Україні, Туреччині, Hiмеччині, Угорщині, Франщії, Польщі, Молдові та інших країнах, а також відбиті в публікаціях - близько 170 статтях, з них 52 надруковано за кордоном. У кількох працях підбито підсумки українсько-турецького співробітництва як прикладу розвитку наукових контактів і успішного вирішення складних проблем спільної історії (Біляєва та ін. 2004; 2006). Узагальнені підсумки досліджень відбито у декількох монографічних працях С. О. Біляевої (2012; 2015а; 2015b). Реконструкцію планувальної структури османської лазні в Аккермані видав Б. Ерсой (Ersoy 2012). Результати досліджень були основою докторської дисертації С. О. Біляєвої «Взаємовідносини східнослов'янського та тюркського світів у XIII-XVIII ст. (за матеріалами археологічних досліджень в Україні)», захищеної 2012 p.

Важливу роль у розгортанні тюркологічних досліджень в Україні, налагодженні співробітництва та координації робіт взяв на себе Науково-дослідний центр «Часи козацькі» разом з Українським товариством охорони пам'яток історії та культури, Центром пам'яткознавства

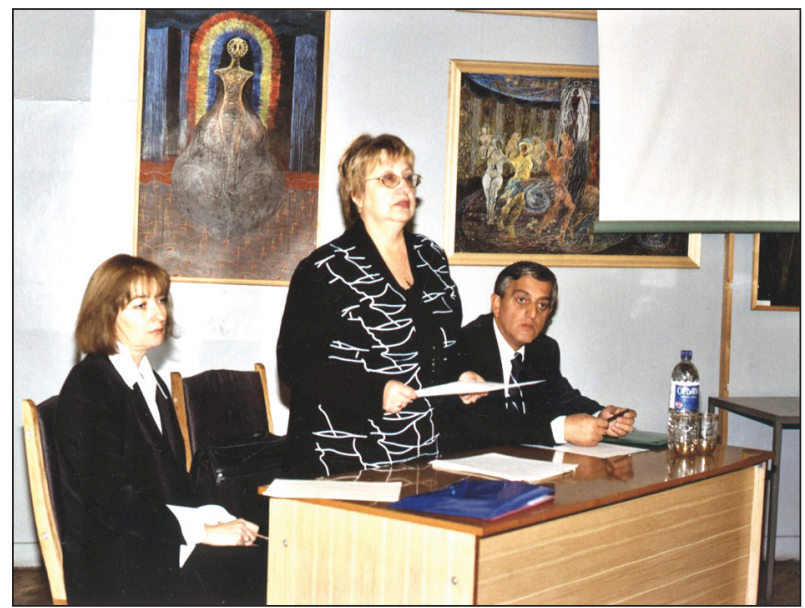

Відкриття урочистих подій з нагоди 80-річчя Турецької Республіки в Археологічному музеї IA НАН України на чолі 3 канд. іст. наук О. М. Титовою, на щорічних конференціях яких виголошено серію тюркологічних доповідей, матеріали секції тюркології оприлюднено у щорічних збірниках конореренції.

\section{ВИСТАВКИ, КОНФЕРЕНЦІЇ, КРУГЛІ СТОЛИ}

Вагомі та різноманітні наукові заходи (конфреренції, презентації видрукуваних праць, виставки археологічних матеріалів) відбувалися у стінах Археологічного музею Інституту археології НАНУ. Матеріали польових досліджень у різних форматах подавалися у 20032006 рр. на чотирьох виставках у Киеві та 2005 р. в Ізмірі.

Знакові події відбувалися за сприяння Посольства Республіки Туреччина та особисто послів Туреччини в Україні: пана Альпа Караосманоглу і пана Більге Джанкореля. 1012 листопада 2003 р. 3 нагоди 80-річчя заснування Турецької Республіки, за ініціативою Інституту археології та за підтримки Посольства Республіки Туреччина, в Археологічному музеї ІА НАНУ відбувся комплекс заходів. Тоді під час конференції вперше було представлено виставку археологічних матеріалів з розкопок Очакова та Аккермана. На відкритті виставки були присутні посол Республіки Туреччини пан Більге Джанкорель з дружиною, а також численні іноземні гості - представники дипломатичних представництв. Підсумки співробітництва підбито у провідному українському журналі «Археологія» (Біляева та ін. 2004).

У 2005 р. за результатами дальших досліджень відбулася друга виставка у Археологічному музеї IA НАНУ, на якій представили числен-

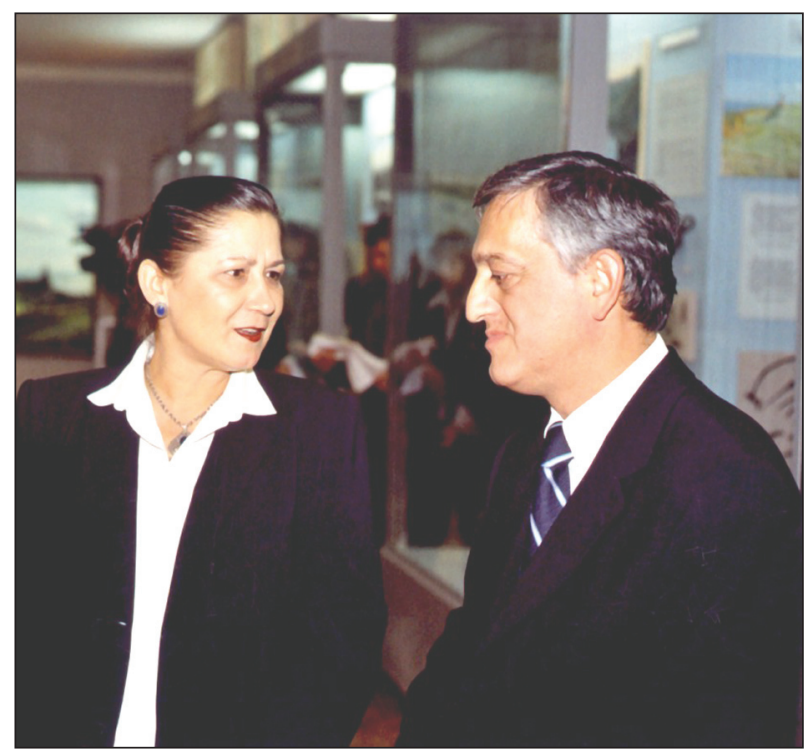

Турецькі вчені: проф. Боскурт Ерсой та проф. Інжі Куйюлу-Ерсой під час відкриття конференції, Київ, 2003 p. 
Відкриття другої виставки в Археологічному музеї за участі Міністра закордонних справ Республіки Туреччини пана Абдулаха Гюля

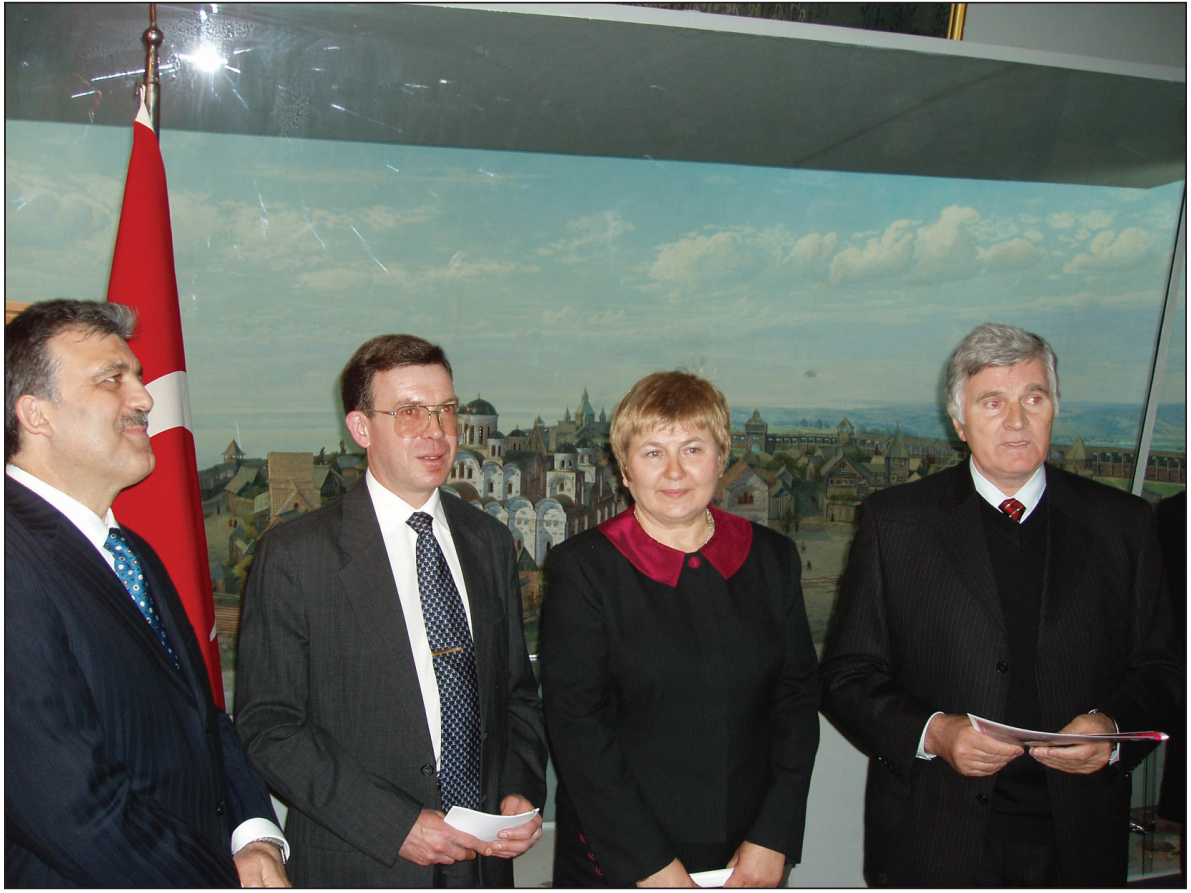

ні знахідки, зокрема монети, прикраси, побутові речі, колекцію глиняних i кам'яних люльок тощо. Виставку відкрили віце-прем'єр, міністр закордонних справ Туреччини Абдуллах Гюль і директор Інституту археології НАН України академік П. П. Толочко. На презентації були присутні: посол Туреччини в Україні Б. Джанкорель 3 дружиною, члени офріційної урядової делегації, яка супроводжувала віце-прем'єра Туреччини в Україну, посли Аргентини, Норвегії, Канади, Сгипту, Литви, Греції, Великобританії, Японії, Ірану, Ізраїлю, Бельгії, Китаю, Італії, Алжиру і представник Ватикану.

Для налагодження подальшого співробітництва, підтримки та координації зв'язків у науковій i культурній сферах, безпосередніх контактів діячів науки i культури, розвитку нових напрямів співробітництва, сприянню діалогу культур двох сусідніх народів за ініціативою С. О. Біляевої та дружини посла Республіки Туреччини в Україні I. Джанкорель у квітні 2005 р. вирішили створити Історико-культурну асоціацію. Тоді ж сорормували Раду засновників у складі С. О. Біляевої, I. Джанкорель, О. Є. Фіалко, Ю. М. Кочубея та А. Ю. Куркова, яка запропонувала заснувати Історико-культурну асоціацію «Україна-Туреччина» (ІКАУТ) і розпочали підготовку Установчих зборів. Головним завданням Асоціащії є об'єднання фрахівців різних галузей науки та громадських діячів для вивчення і збереження культурної та історичної спадщини населення України й Туреччини на теренах Євразії. Основні напрями роботи Асоціації відображають назви восьми тематичних секцій: археологічна, історична, етнографічна, музейної роботи, пам'яткознавства, фрілології та літератури, музична, розвиток історичного туризму.
2 червня 2005 р. відбулися Установчі збори, на яких ухвалили створення Історико-культурної асоціації «Україна-Туреччина», обрали їі Правління та Ревізійну комісію, затвердили Статут. Головою Правління обрали С. О. Біляеву. 11 жовтня 2005 р. Історико-культурна асоціація «Україна - Туреччина» отримала Свідоцтво про державну реєстрацію.

2 грудня у резиденції посла Туреччини в Україні під головуванням почесної голови Правління асоціації І. Джанкорель і в присутності аташе по культурі посольства Туреччини в Україні Ш. Есри відбулася робоча зустріч членів Асоціації та представників організацій, які висловили бажання вступити до неї. На зустрічі заступниця міністра культури України О. Ю. Костенко вітала створення Асоціації і запропонувала участь Міністерства культури України у проведенні «Днів Туреччини в Україні» та «Днів України в Туреччині», в організації виставок і розвитку туризму. В обговоренні пропозицій щодо перспективних напрямів роботи виступили члени Історико-культурної асоціації «Україна-Туреччина» від Інституту археології С. О. Біляєва (голова Правління), О. Є. Фіалко (відповідальний секретар), Ю. В. Болтрик і Л.В.Кулаковська. У обговоренні також взяли участь зав. кафедри педагогіки Київського національного лінгвістичного університету Е. С. Спіцин, співробітники Інституту сходознавства ім. А. Кримського НАН України кандидати іст. наук О. С. Мавріна та Ю. М. Кочубей, док. іст. наук О. Б. Бубенок, канд. фрілолог. наук I. М. Дрига, доцент кафедри тюркології Київського нащіонального університету ім. Т. Шевченка канд. фрілолог. наук T. I. Арнаут, диригент Нащіонального академічного театру опери та балету ім. Т. Шев- 


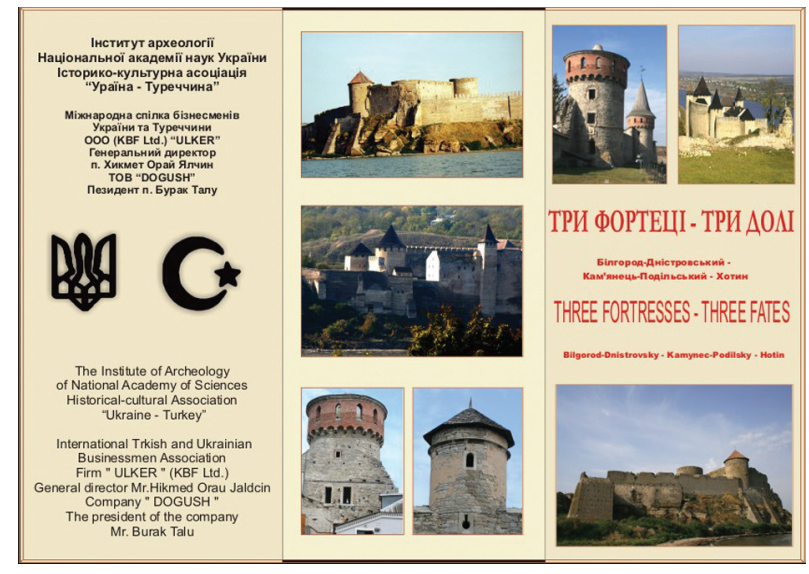

Презентація виставцки «Три фортеці - три долі» ченка Г. І. Макаренко та ін. 9 грудня 2005 р. на засіданні Асоціації створили секції за напрямами діяльності, представили й обговорили перспективні й поточні плани робіт освітнього і науково-дослідницького розділів.

Презентація Асоціації та перші результати ïi роботи обговорювалися під час третьої археологічної виставки, відкритої 22 березня 2006 р. традиційно в Археологічному музеї IA НАНУ. Асоціацію представляли її засновники: голова Правління С. О. Біляєва, заст. голови Правління Ю. М. Кочубей, відповідальний секретар О. Фіалко та член Спілки письменників України А. Ю. Курков.

Восени 2006 р. в Археологічному музеї відбулася чергова виставка під назвою «Три фрор-

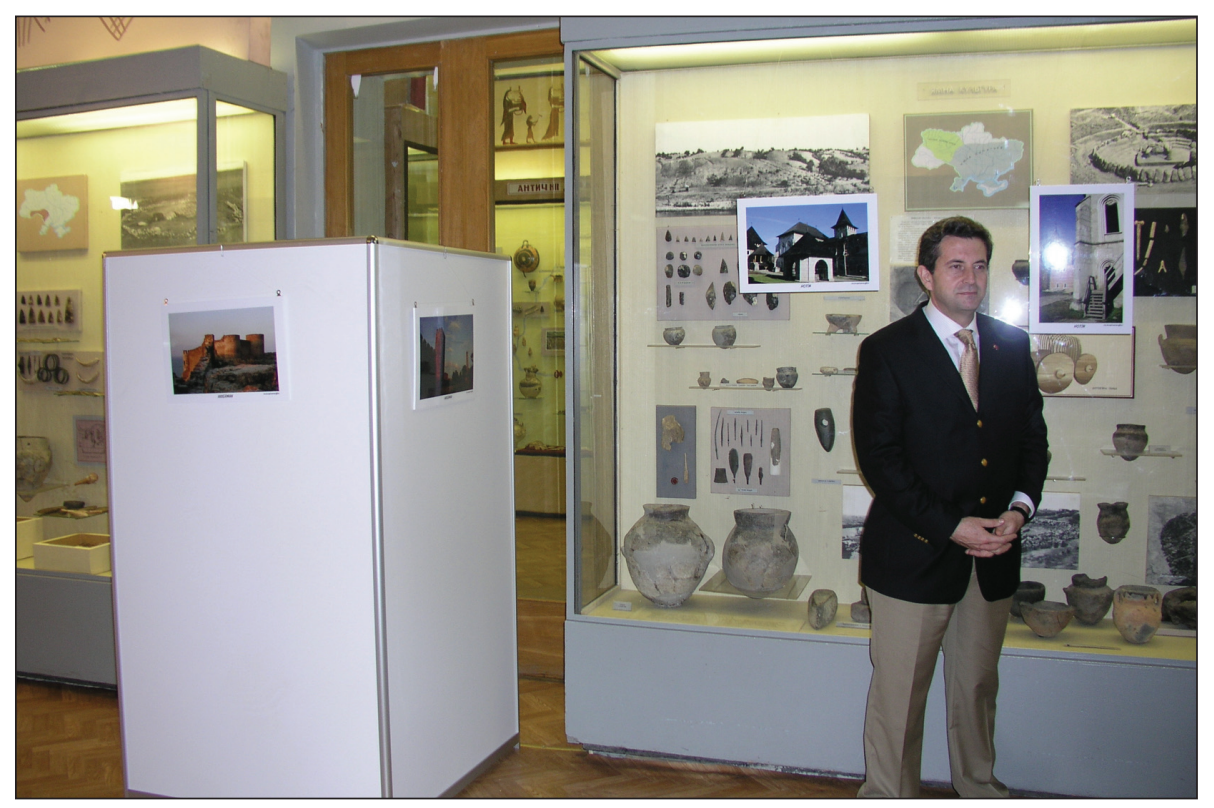

М. Коштумоглу на виставці «Три фортеці - три долі»

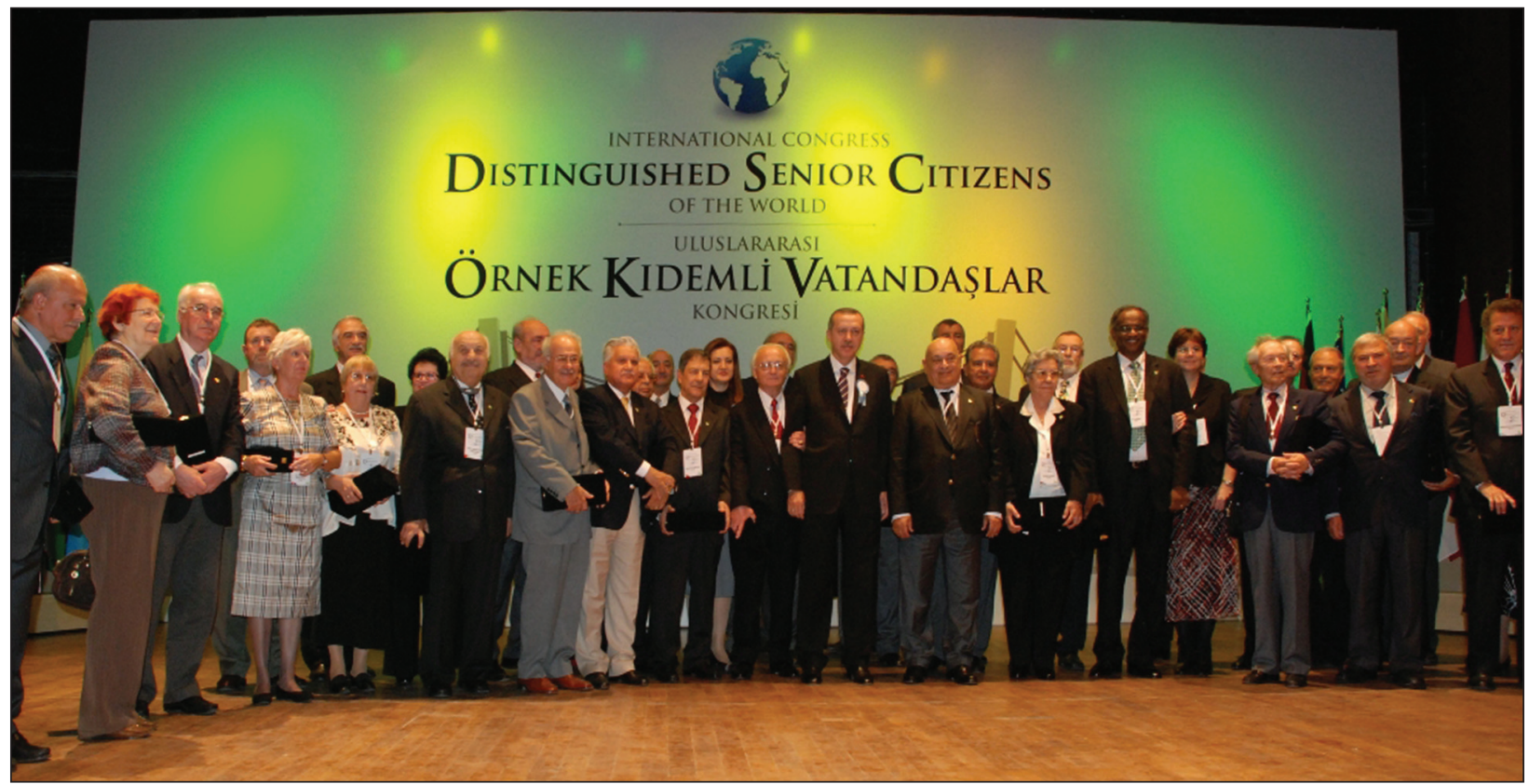

Вручення урочистих відзнак у Стамбулі. У центрі - президент Туреччини (на той час прем'єр-міністр) Р. Ердоган 
тещі - три долі», присвячена минулому трьох фортець, що локалізуються у різних регіонах України: Кам'янець-Подільська - на Поділлі, Хотинська - у Буковині і Білгород-Дністровська (Аккерманська) у Північно-Західному Причорномор'ї. Усі вони перебували певний час під владою Османської імперії. Виставка включала три блоки матеріалів. Перший блок містив опис фортець та їхню стислу історичну характеристику, яку підготувала профо. І. Куйлу-Ерсой. До другого ввійшло 30 світлин пам'яток оборонного зодчества відомого турецького майстра фрото док. М. Коштумоглу. Третій блок презентував результати археологічних досліджень Міжнародної південної середньовічної експедиції у Нижньому дворі Білгород-Дністровської фрортеці, отримані у польові сезони 2005-2006 pр. Спонсорську допомогу у підготовці виставки надали турецькі фрірми, що працюють в Україні, ООО «КБФ» (генеральний директор пан Хикмет Орай Ялчин) і Товариство «Догуш» (президент пан Бурак Талу). Виставку відкрили аташе Посольства Туреччини в Україні пан Ахмет Чанга та інші представники Посольства, а також заступник директора IА НАНУ Г. Ю. Івакін. Серед гостей були співробітники Інституту археології, викладачі Київського національного університету ім. Т. Шевченка, наукові співробітники музеїв і заповідників України.

По завершенню українсько-турецьких проектів матеріали з розкопок Аккермана і Очакова передано на експонування в Археологічний музей IA НАНУ, вони становлять окрему складову розділу археології середньовічної України. Велику роботу з опрацювання матеріалів і підготовки їх до експозиції здійснили співробітники музею, зокрема Л. І. Іванченко.

На Міжнародному конгресі «Подолання бар'єрів між культурами» (Стамбул, 2009 р.), на якому були представники 34 країн, за рі-

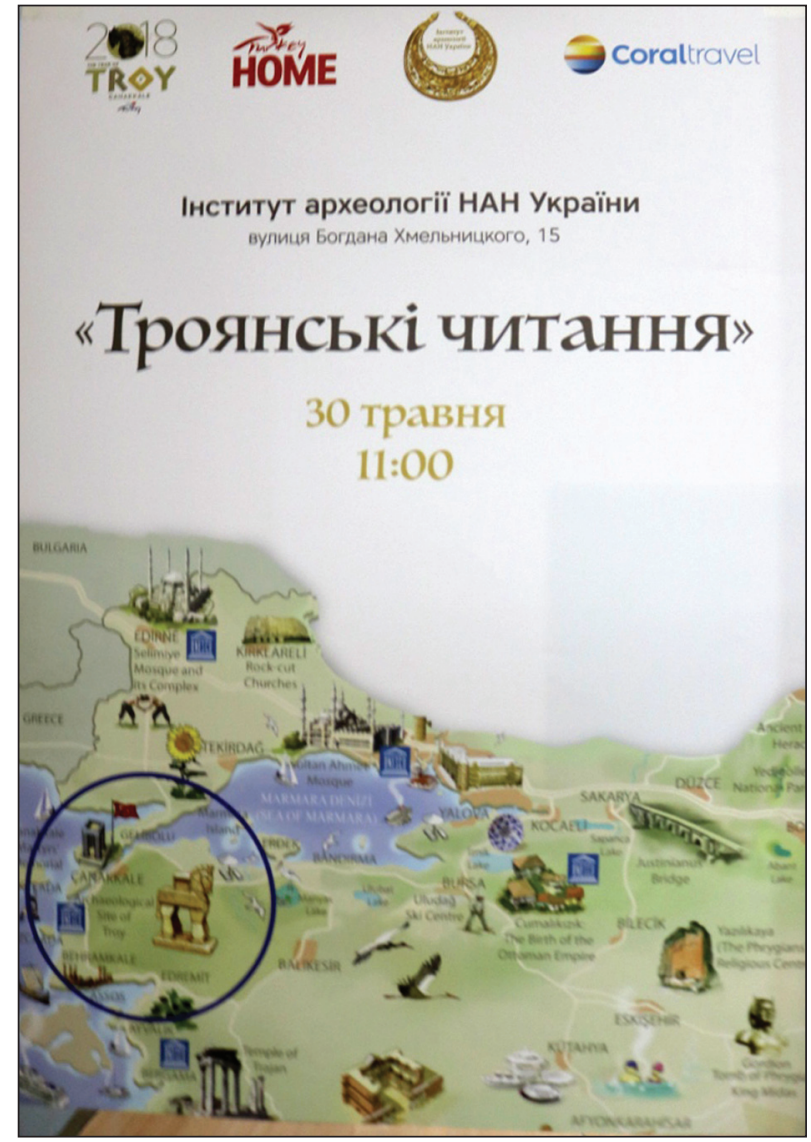

Прес-реліз Троянських читань, Київ, 2018 р.

шенням міжнародної Ради «Туріяк» С. О. Біляєва отримала титул і спеціальну відзнаку «Distinguished Senior Citizen 2009», яку вручив прем'ер-міністр Р. Ердоган (нинішній президент Республіки Туреччина).

10 грудня 2010 р. в Археологічному музеї відбулася презентація, присвячена діяльності ІКАУТ за п’ять років, з ціеї нагоди видали спе-

Троянські читання, виступ академіка П. П. Толочка

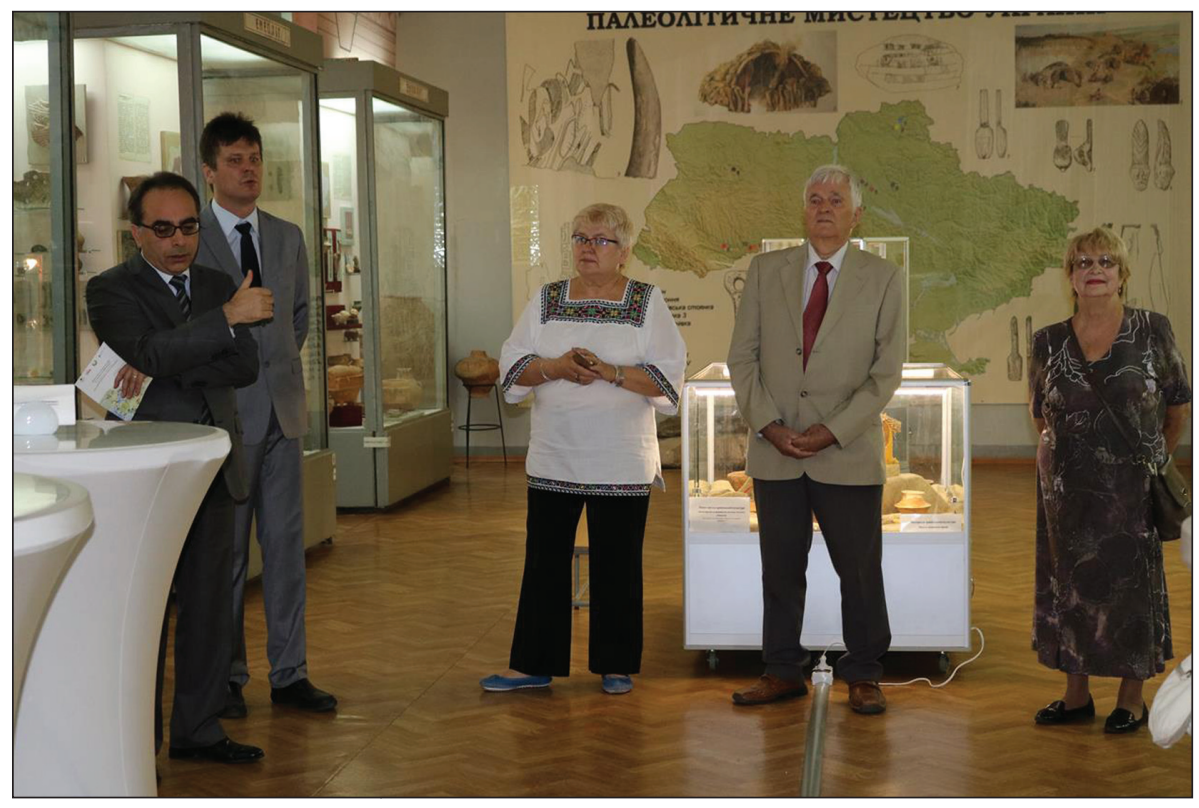


ціальну брошуру «Україна-Туреччина 2010» (Біляева, Дрига, Фіалко 2010), де підведено підсумки діяльності Асоціації. Додамо, що значну роботу у сорері літератури та мови здійснили I. М. Дрига і Т. I. Арнаут.

Значущим підсумком роботи українсько-турецької експедиції стала презентація монографpiï С. О. Біляєвої «Слов'янські та тюркські світи в Україні» (2012), яка відбулася 12 лютого 2013 р. в Археологічному музеї у присутності представників Посольства Республіки Туреччина на чолі з аташе з питань культури і туризму Бератом Йилдизом. Яскравим подарунком для присутніх був виступ художнього танцювального колективу з Переяслава-Хмельницького Державного педагогічного університету ім. Григорія Сковороди. Цей захід висвітлювали ЗМІ Туреччини, зокрема, телебачення.

30 травня 2018 р. за ініціативою уряду Республіки Туреччини і ЮНЕСКО та за сприяння Посольства Турецької Республіки в Україні Інститут археології НАНУ організував Міжнародний симпозіуму «Троянські читання» нагоди оголошення 2018 р. роком Трої. Захід урочисто відкрили посол Республіки Туреччина Йонет Джан Тезель і почесний директор Інституту археології НАНУ академік Петро Петрович Толочко. На засіданнях під головуванням док. іст. наук В. В. Отрощенка були виголошені доповіді провідних вчених України: В.В. Отрощенка, Л. Л. Залізняка, О. С. Фіалко, С. В. Іванової, К. В. Горбенка, М. Ю. Відейка та інших, а також відомого археолога з Росії Л. С. Клейна. Матеріали симпозіуму опубліковано у журналі «Археологія» (Отрощенко, Біляєва 2018).

\section{ВИСНОВКИ}

Розвиток тюркологічних досліджень, наукових і культурних контактів між Україною і Туреччиною започаткували якісно новий етап міжнародного співробітництва двох країн. Дуже важливе місце у співробітництві посідають археологічні дослідження османських пам'яток на теренах України, що уможливили нове бачення історії обох держав - України й Туреччини XV-XVIII ст. З одного боку, це історія східноевропейської частини Османської держави, з іншого - сторінка історії України, що розкриває роль турецького чинника в системі історико-культурних контактів цього часу, розповсюдження та інтеграцію елементів турецької культури в українській.

Важливим чинником історико-археологічних досліджень є сприяння співробітництву, налагодженню контактів на всіх рівнях i opганізаціях з боку Туреччини. Відзначимо, що з 1996 р., коли почалися перші контакти за допомогою Посольства Туреччини, і донині це понад 20 р. добросусідських зв'язків і особистих контактів. Тепер ми просто друзі-вчені різних i таких близьких історично і культурно країн, що дає надію на продовження та поглиблення співробітництва.

\section{Подяки}

Висловлюємо щиру подяку Посольству Республіки Туреччина за постійну опіку і допомогу в проведенні спільних робіт, участь у заходах Інституту археології НАНУ, а також Турецькому історичному товариству, Турецькій агенції зі співробітництва та розвиту (ТІКА) при Раді міністрів Республіки Туреччини, Спілці бізнесменів Туреччини, які працюють в Україні, та всім, хто підтримував і допомагав нам протягом цих років. Особлива подяка керівнику Турецької частини експедиції - профресору Бозкурту Ерсою, проф. Інжі Куйлу-Ерсой, всім колегам із Туреччини, які брали участь у спільних проектах, колективу Археологічного музею IA НАНУ за організацію та проведення виставок і інших наукових заходів.

\section{ЛIТЕРАТУРА}

Беляева, С. А. 2015а. Славяне и тюрки в простоpax Украинь. 1: Из истории контактов в XIII$X V$ в. Saarbrucken: Palmarium academic publishing.

Беляева, С. А. 2015b. Славяне и тюрки в просторах Украины. 2: Украинско-османские историкокультурные контакты XV-XVIII вв. Saarbrucken: Palmarium academic publishing.

Біляева С.О. 2012. Слов'янські та тюркські світи в Украӥні. 3 історї взаємин у XIII-XVIII cm. Київ: Університет Україна.

Біляєва, С. О., Виногродська, Л. І., Сухобоков, О. В., Ерсой, Б. 1998. Археологічні дослідження в Очакові. Археологічні відкриття в Україні 19971998 pp., c. 55-57.

Біляева, С.О., Ерсой, Б. 1998. Підсумки археологічних досліджень історичного центру Очакова у 1997 р. Нові дослідження пал'яток археології козаиької доби в Україні, 7, с. 176-178.

Біляева, С. О., Ерсой, Б. $1999 . \quad$ Дослідження пам'яток османського часу у Північному Причорномор'ї. Археологічні відкриття в Украӥні 1998-1999 pp., c. 73.

Біляева, С. О., Ерсой, Б. 2000. Археологічні дослідження пам'яток османської культури в Україні у 1999 р. Нові дослідження пал'яток козацької доби в Україні, 9, с. 32-35.

Біляева, С. О., Іванченко, Л. І., Кулаковська, Л. В., Фіалко, О. Є. 2004. Нові кроки українсько-турецького співробітництва. Археологія, 3, с. 145-147.

Біляева, С. О., Іванченко, Л. І., Кулаковська, Л. В., Фіалко, О. Є., Ерсой, Б. 2006. Історико-культурна спадщина Туреччини та України: нові дослідження. Відлуння віків, 1, с. 65-68.

Біляева, С. О., Карашевич, І. В., Фіалко, О. Є. 2006. Віконниці в системі архітектурних реконструкцій (османська лазня Аккерманської фортеці). Нові дослідження козацької доби в Україні, 15, c. 277-285.

Біляева, С. О., Болтрик, Ю. В., Ерсой, Б., Карашевич, І. В., Куйлу-Ерсой, І., Фіалко, О. Є. 2007. Дослідження Міжнародної Південної Середньовічної експедиції у 2006 р. в Аккерманській фортеці 
(м. Білгород-Дністровський). Археологічні дослідження в Україні 2005-2007 рр., с. 96-98.

Біляева, С. О., Мартинюк-Медвецька, А. М., Присяжний, К. В. 2008. Історичний розвиток турецького барбакану Портового двору Аккерманської фортеці за результатами археологічно-архітектурних досліджень, проведених у 2006-2007 роках. Нові дослідження козацької доби в Україні, 17 , c. $350-355$.

Біляева, С. О., Дрига, І. М., Фіалко, О. С. 2010 Украӥна-Туреччина 2010. Археологія - історія культура - література - мова. Київ: Видавничий дім Дмитра Бураго.

Біляева, С. О., Фіалко, О. Є. 2018. Планіграфрія та типологічна характеристика скляних виробів з Аккерману. Археологія $і$ давня історія України, 4 (29), c. $133-148$.

Отрощенко, В. В., Біляєва, С. О. 2018. Рік Трої в Україні. Археологія, 4, с. 3-4.

Шлапак, М. 2001. Белгород-Днестровская крепость. Исследование средневекового оборонного зодчества. Кишинев: ARC.

Baram, U., Carrol, L. (ed.). 2000. A historical archaeology of the Ottoman Empire. Breaking New Ground. New York: Springer Science Business Media.

Biliaieva, S. 1999. Ochakiv deki Turk sehrinde Arkeolojik Arastirmal. In: Aktash, A. (ed.). Uluslarasi Dxrduncü Türk Kültürü Kongresi 1997. Ankara: Atatürk Kültür Merkezi Bashkanligi, p. 109-114.

Biliaieva, S., Ersoy, B. 1999. Ôzi Kalesi (Ukrayna Ochakiv) Arkeolojik Calişmalari. In: Aktash, A. (ed.). Uluslarasi Dxrduncü Türk Kültürü Kongresi 1997. Ankara: Atatürk Kültür Merkezi Bashkanligi, p. 263-268.

Ersoy, B. 2012. Akkerman kalesi, osmanli hamami. In: 3ilingiroplu, A., Mercangö̈z, Z., Polat, G. (ed.). Ege Üniversitesi Arkeoloji kazilari. Izmir: Ege Üniversitesi, p. 338-348.

Finkel, C., Biliaieva, S., Haddlssey, R., Mathieu, J., Ostapchuk, V. 2007. Historical-archaeological investigations in Aqkerman fortress, Ukraine 2007 Anatolian archaeology, 13, p. 11-14.

Finkel, C., Ostapchuk, V. 2005. Outpost of Empire: an appraisal of Ottoman building registers as sources for the archaeology and construction history of the Black Dea fortress of Ozi. An annual on the visual culture of the Islamic World, 22, p. 176-179.

Finkel, C., Ostapchuk, V., Biliaieva, S., Mathieu, J. 2006. Historical-archaeological investigations in Aqkerman fortress, Ukraine 2006. Anatolian archaeology, 12, p. 9-12.

\section{REFERENCES}

Beliaieva, S. A. 2015a. Slaviane $i$ Turki u prostorah Ukrainy. 1: Iz istorii kontaktov v XIII-XV v. Saarbrucken: Palmarium academic publishing.

Beliaieva, S. A. 2015b. Slaviane $i$ Turki u prostorah Ukraini. 2: Ukrainsko-osmanskie istoriko-kulturnyie kontaktyi $X V-X V I I I v v$. Saarbrucken: Palmarium academic publishing.

Biliaieva, S. O. 2012. Slovianski ta turkski svity v Ukraini. $Z$ istorii vzayemyn u XIII-XVIII st. Kyiv: Universitet Ukraina.

Biliaieva, S. O., Vynogrodska, L. I., Suhobokov, O. V., Ersoy, B. 1998. Arkheolohichni doslidzhennia v Ochakovi. Arheokogichni vidkrittya v Ukraini 1997-1998 rr., s. 55-57.
Biliaieva, S. O., Ersoy, B. 1998. Pidsumky arheologichnyh doslidzhen istorichnogo tsentru Ochakova u $1997 \mathrm{r}$. Novy doslidzhennya pamyatok archeologii kozatskoy doby $v$ Ukraini, 7, s. 176-178.

Biliaieva, S. O., Ersoy, B. 1999. Doslidzhennya pamyatok osmanskogo chasu u Pivnichnomu Prychornomoryi. Arheologichni vidkryttya $v$ Ukraini 1998-1999 rr., s. 73

Biliaieva, S. O., Ersoy, B. 2000. Arheologichni doslidzhennya pamyatok osmanskoy kultury v Ukraini u 1999 r. Novi doslidzhennya pamyatok archeologii kozatskoy doby v Ukraini, 9, s. 32-35.

Biliaieva, S. O., Ivanchenko, L. I., Kulakovska, L. V., Fialko, O. Ye. 2004. Novi kroky ukrainsko-turetskogo spivrobitnytstva. Arheologiya, 3, s. 145-147.

Biliaieva, S. O., Ivanchenko, L. I., Kulakovska, L. V., Fialko, O. Ye., Ersoy, B. 2006. Istoryko-kulturna spadschyna Turechchyny i Ukrainy: novi doslidzhennya. Vidlunnya vikiv, 1 , s. 65-68.

Biliaieva, S. O., Karashevych, I.V., Fialko, O. Ye. 2006. Vikonnyitsi v systemi arhitekturnyh rekonstruktsiy (osmanska laznya Akkermanskoy fortetsi). Novi doslidzhennya pamyatok archeologii kozatskoy doby v Ukraini, 15, s. $277-285$

Biliaieva, S. O., Boltryk, Yu. V., Ersoy, B., Karashevych, I. V., Kuyulu-Ersoy, I., Fialko, O. Ye. 2007. Doslidzhennya Mizhnarodnoy Pivdennoy Seredniovichnoy ekspeditsii u 2006 r. v Akkermanskoy fortetsi (m. Bilgorog-Dnistrovskiy). Arheologichni doslidzhennya v Ukraini 2005-2007 rr., s. 9698

Biliaieva, S. O., $\quad$ Martynyuk-Medvetska, A. M., Prysyazhnyi, K. V. 2008. Istorichnyi rozvytok Turetskogo barbakianu Portovogo dvoru Akkermanskoy fortetsi za rezultatamy arheologichno-arhitekturnyh doslidzhen, provedenyh u 2006-2007 rokah. Novi doslidzhennya pamyatok archeologii kozatskoy doby $v$ Ukraini, 17, s. 350-355.

Biliaieva, S. O., Dryga, I. M., Fialko, O. Ye. 2010. Ukraina-Turechchyna 2010. Arheologiya - istoriya - kulturamova. 2010. Kyiv: Vidavnichiy dim Dmytra Burago.

Biliaieva, S. O., Fialko, O. Ye. 2018. Planigrafiya ta typologichna harakteristyka sklyanyh virobiv z Akkermanu. Arheologiya i davnya istoriya Ukrainy. 4 (29), s. 133-148.

Otroshchenko, V. V., Biliaieva, S. O. 2018. Rik Troi v Ukraini. Arheologiya, 4, s. 3-4.

Shlapak, M. 2001. Belgorod-Dnestrovskaia krepost. Issledovanie srednevekovogo oboronnogo zodchestva. Kishinev: ARC

Baram, U., Carrol, L. (ed.). 2000. A historical archaeology of the Ottoman Empire. Breaking New Ground. New York: Springer Science Business Media.

Biliaieva, S. 1999. Ochakiv deki Turk sehrinde Arkeolojik Arastirmal. In: Aktash, A. (ed.). Uluslarasi Dxrduncü Türk Kültürü Kongresi 1997. Ankara: Atatürk Kültür Merkezi Bashkanligi, p. 109-114.

Biliaieva, S., Ersoy, B. 1999. Őzi Kalesi (Ukrayna-Ochakiv) Arkeolojik Calismalari. In: Aktash, A. (ed.). Uluslarasi Dxrduncü Türk Kültürü Kongresi 1997. Ankara: Atatürk Kültür Merkezi Bashkanligi, p. 263-268.

Ersoy, B. 2012. Akkerman kalesi, osmanli hamami. In: 3ilingiroplu, A., Mercangổz, Z., Polat, G. (ed.). Ege Üniversitesi Arkeoloji kazilari. Izmir: Ege Ǘniversitesi, p. 338-348.

Finkel, C., Biliaieva, S., Haddlssey, R., Mathieu, J., Ostapchuk, V. 2007. Historical-archaeological investigations in Aqkerman fortress, Ukraine 2007 Anatolian archaeology, 13, p. $11-14$

Finkel, C., Ostapchuk, V. 2005. Outpost of Empire: an appraisal of Ottoman building registers as sources for the archaeology and construction history of the Black Dea fortress of Ozi. An annual on the visual culture of the Islamic World, 22, p. 176-179.

Finkel, C., Ostapchuk, V., Biliaieva, S., Mathieu, J. 2006. Historical-archaeological investigations in Aqkerman fortress, Ukraine 2006. Anatolian archaeology, 12, p. 9 12 . 


\section{UKRAINE - TURKEY: THE VERGES OF COOPERATION}

The formation of the scientific cooperation of Ukraine and Turkey began from the beginning of independence state, after crushing of Soviet ideological system. From 1989. the archaeological investigations of historical center of Ochakiv (Mikolayiv region) begin by expedition of the Institute of archaeology of NAN of Ukraine. The study of new collection, which include numerous artefacts of Turkish culture needed with consultations with Turkish archaeologists. Due to help of the Ambassador of Turkey in Ukraine Acar Germen, the first international contacts were established and in 1997-1998. first project in Ochakiv provided under the chief of prof. B. Ersoy from Turkish side. In 1999 began joint the excavation in Akkerman, which continue till 2006. The results of expedition published in numerous books and articles. The next direction of cooperation were exhibitions, which take place in Kiev and Izmir. In 2005. the historical and cultural association Ukraine-Turkey created, member of which represented various fields of study: archaeology, history, literature and language. A very important place take archaeological investigation of the Ottoman monuments on the territory of Ukraine, which allow to discover new view on the history both of countries, reconstruction of integrations in the system of material culture.

Keyworlds: cooperation, Ukraine, Turkey, archaeological investigations.
БІЛЯСВА Світлана Олександрівна, доктор історичних наук, старший науковий співробітник, Інститут археології НАН України, пр. Героїв Сталінграда, 12, Київ, 04210, Україна.

BILIAIEVA Svitlana Oleksandrivna, Doctor of Historical Sciences, Senior Research Fellow, Institute of Archaeology, National Academy of Sciences of Ukraine, Heroiv Stalingradu ave., 12, Kyiv, 04210, Ukraine. ORCID: orcid.org/0000-0003-3113-7619, e-mail: svitbil@ukr.net.

кУЛАКОВСЬКА Лариса Віталіївна, кандидат історичних наук, завідувач відділу, Інститут археології НАН України, пр. Героїв Сталінграда, 12, Київ, 04210, Україна.

KULAKOVSKA Larisa Vitaliivna, Candidate of historical sciences, Senior Research Fellow, Institute of Archaeology, National Academy of Sciences of Ukraine, Heroiv Stalingradu ave., 12, Kyiv, 04210, Ukraine. ORCID: orcid.org/0000-0002-8704-8642, e-mail: larisav@ukr.net.

ФІАЛКО Олена Свгенівна, кандидат історичних наук, старший науковий співробітник, Інститут археології НАН України, пр. Героїв Сталінграда, 12, Київ, 04210, Україна.

FIALKO Olena Yevgenivna, Candidate of Historical Sciences, Senior Research Fellow, Institute of Archaeology, National Academy of Sciences of Ukraine, Heroiv Stalingrada ave., 12, Kyiv, 04210, Ukraine. ORCID: orcid.org/0000-0002-4976-3266, e-mail: ofialka@ukr.net. 